\title{
Spontaneous haemorrhage in a healthy newborn
}

\author{
Eulália Viveiros, ${ }^{1}$ Marcos Sanches, ${ }^{2}$ Alexandra Couto, ${ }^{3}$ Helena Ramos ${ }^{3}$
}

${ }^{1}$ Pediatric Department, Hospital do Divino Espírito Santo de Ponta Delgada, EPE, Ponta Delgada, Azores, Portugal ${ }^{2}$ Pediatric Department, Hospital Distrital de Santarém, EPE, Santarém, Portugal

${ }^{3}$ Department of Neonatal Intensive Care, Maternidade Dr Alfredo da Costa, Lisboa, Portugal

\section{Correspondence to} Dr Eulália Viveiros, eulaliaviveiros@gmail.com

Accepted 3 May 2014

\section{DESCRIPTION}

A full-term male neonate, who was born by vaginal delivery without trauma, presented a small purple tumefaction on his back at $8 \mathrm{~h}$ of life, with a tender consistency. It was well defined and interpreted as a haemangioma. At $24 \mathrm{~h}$ of life he became lethargic, pale, tachycardic and the tumefaction worsened (figures 1 and 2). ${ }^{12}$ A careful review of his family history revealed haemophilia $\mathrm{A}$ in first-degree to third-degree relatives on the maternal side. ${ }^{1}{ }^{2}$ Haemoglobin dropped from 14.6 to $9.5 \mathrm{~g} / \mathrm{dL}$ in $4 \mathrm{~h}$. His activated thromboplastin time was $85.2 \mathrm{~s}$ with normal prothrombin time and number of platelets. The coagulation factor dosage revealed a severe factor VIII deficiency (FVIII <0.1\%). He received red blood cells, fresh frozen plasma and intravenous recombinant factor VIII transfusions, and started phototherapy for jaundice. ${ }^{2}$ Cranial, abdominal ultrasounds and thorax radiographies were normal. In the following days, his general condition and haematoma significantly improved.
He was discharged at 7 days of life with FVIII dosage in normal range (85.2\%) and negative inhibitors for FVIII.

\section{Learning points}

- Haemophilia A is an X-linked coagulation disorder, so mothers are usually asymptomatic carriers and manifestations are almost exclusively in male neonates.

- A review of the family history in an otherwise healthy newborn, with unexplained bleeding, can lead to the diagnosis in two-thirds of the population.

- The severe form of haemophilia should be part of the differential diagnosis of haemodynamically unstable newborns with spontaneous superficial haematoma.

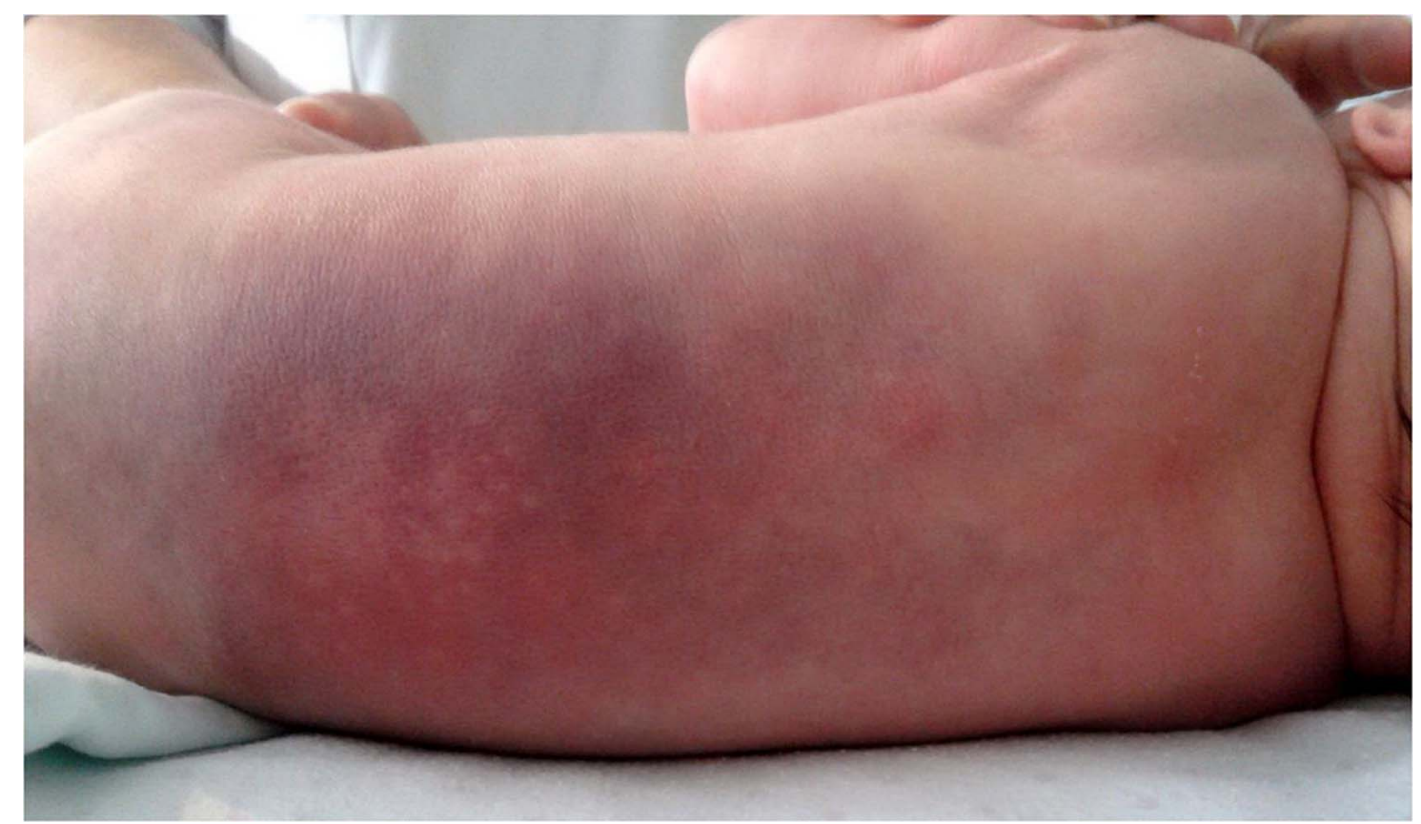

Figure 1 Diffuse haematoma on the neonate's back and the presence of some central yellowish papule surrounded by a halo of erythema (erythema toxicum). 
Figure 2 Extensive haematoma on the back of the neonate.

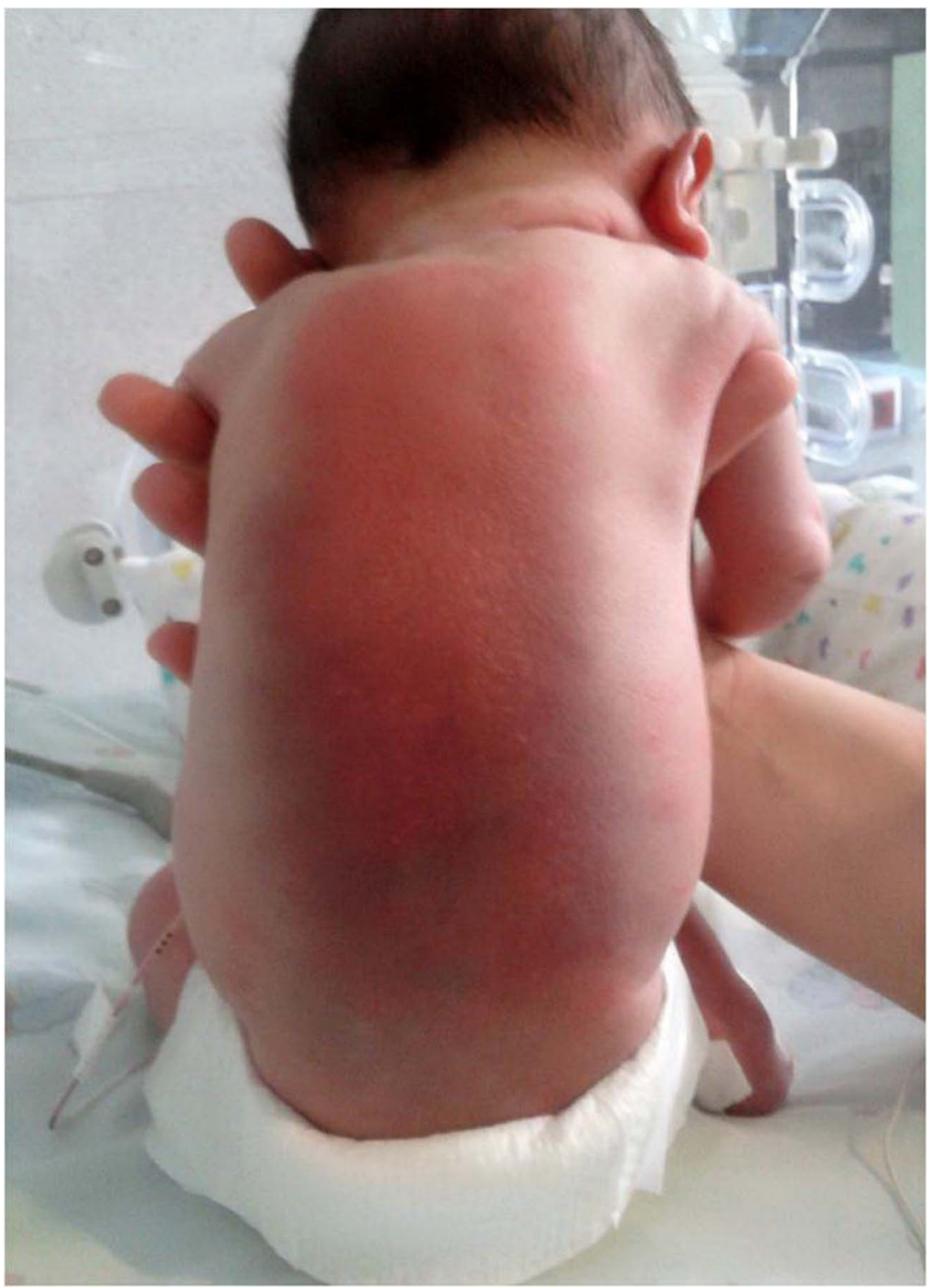

\section{REFERENCES}

1 Chalmers EA. Neonatal coagulation problems. Arch Dis Child Fetal Neonatal Ed 2004:89:F475-8.

2 Dyson $\mathrm{H}$. Neonatal haemophilia—a guide for recognition and management. Haemophilia 2006;2:156-9.

\section{Patient consent Obtained.}

Provenance and peer review Not commissioned; externally peer reviewed.

Copyright 2014 BMJ Publishing Group. All rights reserved. For permission to reuse any of this content visit http://group.bmj.com/group/rights-licensing/permissions.

BMJ Case Report Fellows may re-use this article for personal use and teaching without any further permission.

Become a Fellow of BMJ Case Reports today and you can:

- Submit as many cases as you like

- Enjoy fast sympathetic peer review and rapid publication of accepted articles

- Access all the published articles

- Re-use any of the published material for personal use and teaching without further permission

For information on Institutional Fellowships contact consortiasales@bmjgroup.com

Visit casereports.bmj.com for more articles like this and to become a Fellow 